\title{
Studi Analisis Komite Sekolah/Madrasah dalam Mengawal Kualitas Pendidikan
}

\author{
Abdul Mukti Bisri \\ ${ }^{1}$ Pascasarjana Institut Pesantren Kh. Abdul Chalim Pacet Mojokerto \\ e-mail: muktibisri.ikhac@gmail.com
}

Submitted: 01-01-2020 Revised : 15-02-2020 Accepted: 03-03-2020

\begin{abstract}
Dibentuknya komite sekolah/madrasah adalah upaya penyesuaian terhadap paradigma yang dirubah oleh pemerintah menjadi desentralisasi. Hal ini menjadi peluang bagi stakeholder khusunya masyarakat agar dapat memberikan ruang untuk ikut serta dalam mengelola pendidikan. Kebijakan pendidikan di Negara kita sekarang ini seharusnya dapat membangun manusia yang kompetitif. Sebagian sekolah/madrasah yang kita miliki dan pendidikannya mumpuni, akan tetapi hasil yang didapatkan belum maksimal hanya karena tidak memiliki partner yang dapat membantu dan mengawal kualitas pendidikannya. Studi analisis ini merupakan upaya untuk menganalisis kebijakan pendidikan terhadap komite sekolah/madrasah dan menelaah peran, fungsi, maupun tugasnya ketika berupaya mengembangkan dan meningkatkan kualitas pendidikan. Sebab keikutsertaan komite sekolah/madrasah dalam pengembangan dan peningkatan sekolah sangat diperlukan, yang akhirnya dapat memberdayakan seluruh komponen masyarakat. Dan yang paling penting komite sekolah/madrasah dapat mewujudkan apa yang diharapkan oleh masyarakat.
\end{abstract}

Keywords: Komite Sekolah, Kualitas Pendidikan, Madrasah, Sekolah

https:

How to Cite Abdul ukti Bisri. (2020). Stdui Aanalisis Komite Sekolah/Madrasah dalam Mengawal Kualitas Pendidikan. Munaddhomah: Jurnal Manajemen Pendidikan Islam, Volume 1 (1), 51-64.

\section{PENDAHULUAN}

Sumber daya manusia perlu ada peningkatan dalam segi kualitasnya, oleh karena itu pemerintah berusaha mewujudkannya melalui berbagai macam usaha yang salah satunya mengembangkan kualitas pendidikan melalui perbaikan dan pengembangan kurikulum serta system evaluasi. Dan dari segi yang lainnya pun juga dikembangkan dan ditingkatkan, seperti sarana prasarana, pengadaan bahan ajar, workshop bagi pendidik dan tenaga kependidikan, serta masih banyak yang lain.(Krissandi \& Rusmawan, 2015, p. 457)

Namun realitanya, semua pengembangan dan perbaikan tersebut belum memnuhi dalam mwujudkan pendidikan yang berkualitas. Sehingga diantaranya ada yang berupaya untuk mengembangkan salah satu komponen seperti kurikulum yang berlaku agar lebih inovatif dan produktif.(Hakim \& Hasan, 2019, p. 4) Akan tetapi upaya ini hanya dapat dilakukan apabila seluruh unsur dari lembaga pendidikan maupun masyarakat ikut berpartisipasi, baik dari dalam maupun luar lingkungan sekolah.

Salah satu wujud aktualisasinya dengan dibentuk sebuah badan pendamping, yang organisasinya terdiri dari stakeholder. Sampai saat ini, telah terjadi perubahan berkali-kali pada organisasi ini karena disesuaikan dengan perkembangan pendidikan maupun masyarakat. Awal mula organisasi ini diberi nama (POMG) Perkembangan Orang tua Murid dan Guru, kemudian 
berkali-kali mengalami perubahan sampai saat ini disebut komite sekolah/madrasah.(Sa'ud \& Makmun, 2009, p. 6)

Sejarah perubahan nama BP3 menjadi badan komite sekolah/madrasah berdasarkan atas perlunya partisipasi seluruh elemen masyarakat secara loyal dalam upaya meningkatkan kualitas pendidikan. Hal ini juga ditunjang dengan adanya tujuan dalam pembentukan badan komite sekolah/madrasah yaitu menambah rasa tanggung jawab dan peduli terhadap pelaksanaan dan pengembangan kualitas pendidikan di suatu lembaga pendidikan.(Hakim, 2016, p. 107)

Pembentukan komite sekolah/madrasah merupakan upaya adanya suatu organisasi masyarakat yang memiliki kepedulian terhadap peningkatan kualitas pendidikan. Badan komite sekolah/madrasah ini dapat dikembangkan oleh semua pihak baik lembaga pendidikan maupun dari pihak komite sendiri. Hal ini dapat dilakukan dengan cara merujuk dari kesepakatan dan kepercayaan yang telah dibangun sesuai dengan potensi yang dimiliki masyarakat sekitar.

Kepedulian masyarakat sangat dibutuhkan dalam hal pengembangan pendidikan, bukan hanya seperti sekarang yang sebagian besar memberi bantuan material saja, namun seharusnya perlu menyisihkan waktunya juga agar dapat membantu lembaga pendidikan minimal berupa ideide kreatif, gagasan yang inovatif demi kemajuan kualitas suatu sekolah. Oleh karena itu, masyarakat merupakan salah satu bagian penting dari lembaga pendidikan yang akan ikut andil sebagai stakeholder pendidikan(Ridwan, 2018).

Peran dan fungsi dewan pendidikan maupun komite sekolah/madrasah pada dasarnya adalah untuk meningkatkan kualitas pendidikan di masing-masing wilayahnya, apabila dewan pendidikan maupun komite sekolah/madrasah betul-betul melaksanakan peran dan fungsinya dengan baik tentu akan mampu mengembangkan kinerja para pengelola pendidikan yang mana kebutuhan untuk proses pendidikan akan terpenuhi..(Sagala, 2008, p. 53)

Dan juga perlu badan komite sekolah/madrasah ini memotivasi masyarakat dari semua kalangan bawah sampai atas untuk berpartisipasi serta mewujudkan hubungan kerja sama yang produktif. Tentunya hal ini sangat berarti bila dilakukan dengan seluruh stakeholder pendidikan, terkhusus dengan dunia usaha maupun industri di masing-masing daerah.

Komite sekolah/madrasah sebagai badan pemberi pertimbangan, diharapkan memberikan pertimbangan, saran, dan rekomendasi terhadap pihak lembaga pendidikan terkait semua kebijakan dan program-program sekolahnya.(Mas, 2011, pp. 186-187) Sebagai peran pendukung, komite sekolah/madrasah juga dapat mendorong wali murid untuk ikut andil dalam pendidikan.(Desi Nurhikmahyanti, 2014, p. 169) Sebagai pendukung pula, bentuk peran komite sekolah/madrasah dapat diwujudkan dengan menggalang donasi dari banyak pihak yang bertujuan untuk biaya operasional pendidikan.(Rusdiana, 2014, p. 153)

Dengan demikian, dalam konteks operasional komite sekolah/madrasah dalam upaya peningkatan kualitas pendidikan tidak dibatasi hanya dalam hal budgeting dan biaya sekolah saja, namun ikut terlibat secara aktif dalam menyusun kebijakan dan program sekolah, khususnya terkait rencana strategik. Lembaga pendidikan juga mengharapkan badan komite sekolah/madrasah ini dapat berperan aktif dalam penyusunan dan realisasi visi, misi, tujuan, dan program-program sekolah, sehingga nantinya juga ikut terlibat aktif dalam pengawasan dan evaluasi pelaksanaan program lembaga pendidikan.

\section{KOMITE SEKOLAH/MADRASAH}

Keinginan pemerintah menyerahkan sebagian pengelolaan pendidikan kepada daerah seyogyanya disambut dengan cara ikut aktif dalam pengelolaan pendidikan oleh anggota masyarakat.(Fauziyati, 2018, p. 174) Sistem manejemen mutu yang baik mengakomodasi seluruh potensi yang dimiliki. Hal ini dimanifestasikan dengan adanya otonomi daerah yang dalam dunia pendidikan diimplementasikan dengan manajemen berbasis sekolah/madrasah. Yang memiliki kewenangan lebih dalam segala keputusan strategis yang berkaitan dengan lembaga secara otonom.(Hakim, 2016, p. 107) 
Sistem manajemen berbasis sekolah ini digunakan agar lembaga lebih mudah dalam meningkatkan kualitas pendidikan, salah satunya melalui kerjasama dengan masyarakat sebagai stakeholder pendidikan yang selama ini dirasa belum bisa mewujudkan harapan masyarakat sebagai pengguna utama pendidikan.(Sudirman, 2013, p. 188)

Untuk menampung aspirasi dan menyalurkan partisipasi masyarakat dalam proses penyelenggaraan pendidikan di setiap satuan pendidikan, dibuatlah institusi berupa komite sekolah/madrasah.(Faqih \& Mulianti, 2016, p. 110) Institusi ini dapat digunakan sebagai wadah yang representative, karena dianggap dapat mewujudkan kualitas, pemerataan, dan efektifitas dalam pengelolaan pendidikan.

Lembaga komite sekolah/madrasah mrupakan lembaga mandiri yang beranggotakan wali murid, masyarakat secara luas, dan komunitas sekolah yang peduli dengan pendidikan. Dan dibentuknya komite sekolah/madrasah berperan dalam meningkatkan kualitas pelayanan pendidikan, serta dukungan maupun arahan bagi seluruh komponen yang ada di tingkat satuan pendidikan. Terlebih dapat membantu dalam hal pengawasan selama satuan pendidikan tersebut aktif.(Sudirman, 2013, p. 188)

Dalam kebijakan otonomi pendidikan, peranan masyarakat lebih dimaksimalkan karena tidak hanya menjadi donatur semata tapi juga perlu dilibatkan dalam upaya pengembangan pendidikan. Secara lebih jelas legalilitas komite sekolah/madrasah di lembaga pendudikan dinaungi oleh Keputusan Menteri Pendidikan Nasional Nomer 044/U/2002 yang membahas terkait Dewan Pendidikan dan komite sekolah/madrasah bahwa setiap satuan pendidikan diharuskan untuk membentuk komite sekolah/madrasah. Komite sekolah/ madrasah diharapkan dalam setiap menjalankan kebijakan pendidikan juga meningkatkan kontrol kinerja satuan pendidikan.(Faqih \& Mulianti, 2016, p. 110)

Dari semua penjelasan terkait komite sekolah/madrasah di atas, dapat kita simpulkan garis besarnya bahwa pengertian komite sekolah/madrasah adalah lembaga independen dari unsur masyarakat, sekolah, dunia usaha, wali/orang tua peserta didik yang menjadi wadah aspirasi dalam rangka meningkatkan mutu pendidikan dalam segala tingkatan dan jalur pendidikan.

\section{TUJUAN KOMITE SEKOLAH/MADRASAH}

Permasalahan selama proses pendidikan tidak mungkin dapat teratasi hanya oleh lembaga pendidikan. Untuk menyelesaikannya serta melaksanakan semua progamnya, pihak sekolah perlu mengikut sertakan keluarga, masyarakat, dan du-di (dunia usaha dan industri) dalam berpartisipasi secara aktif dalam berbagai program pembelajaran dan pendidikan.(Kamil, 2007, pp. 14-15)

Kerjasama ini sangat perlu dikelola dan koordinasi yang baik, terutama dalam hal peningkatan mutu dan efektifitas pendidikan melalui suatu wadah yaitu komite sekolah/madrasah di setiap satuan pendidikan.(Fauziyati, 2018, pp. 158-159) Dengan demikian, pelaksanaan manajemen berbasis sekolah di satuan pendidikan dapat terlaksana sesuai harapan.

Dibentuknya komite sekolah/madrasah dimaksudkan agar masyarakat yang bersatu dalam sebuah wadah organisasi ini mempunyai komitmen dan loyalitas serta kepedulian terhadap peningkatan kualitas pendidikan. Komite sekolah/madrasah yang dibentuk antara warga masyarakat dan sekolah bisa berciri khas dan berakar dari budaya masyarakat setempat.(Desi Nurhikmahyanti, 2014, p. 169) Hal ini mendasari dalam pengembangan komite sekolah/madrasah untuk organisasi pengguna, berbagi kewenanagan dan kemitraan (partnership) yang fokus kajiannya pada peningkatan kualitas pelayanan pendidikan. Tujuan dari di bentuknya komite sekolah/madrasah adalah: a) Memuat dan menyalurkan aspirasi masyarakat dalam menciptakan kebijakan operasioanal dan program pendidikan. b) Membuat masyarakat sadar akan tanggung jawab dan perannya dalam upaya penyelenggaraan pendidikan. c) Mewujudkan kondisi yang demokratis, transparan, dan akuntabel dalam penyelenggaraan maupun pelayanan pendidikan yang bermutu.(Anwar, 2015, pp. 169-170)

Dengan demikian, komite sekolah/madrasah dibentuk untuk menjadi wadah agar stakeholder selama ikut andil dalam operasional manajemen sekolah sesuai dengan fungsi dan perannya. 
Bahkan yang berkaitan dengan perencanaan, pelaksanaan, evaluasi maupun kebijakan sekolah secara proposional, sehingga komite sekolah/madrasah lebih aktif meningkatkan transparansi dan akuntabilitas pengelolaan pendidikan.

Jika melihat secara kesuluruhan, tujuan awal komite sekolah/madrasah ini untuk merekonstruksi manajemen sekolah agar dapat merubah kegiatan rutinitas dengan memberi tanggung jawab kepada komite sekolah/madrasah baik keputusan maupun kebijakan pada tingkat satuan pendidikan. Yang akhirnya, pihak lembaga pendidikan dan kepala sekolah sebagai pemimpin lembaga pendidikan harus membuat rencana strategis terlebih dahulu.

Untuk dinas pendidikan perlu membuat atau merancang rencana strategis daerah dengan fokus pada hal-hal berikut ini:

a. Identifikasi terhadap tekanan yang berasal dari luar dan dalam daerah

b. Memberi penjelasan terkait keyakinan dan nilai-nilai pendidikan

c. Menetapkan dan mengembangkan visi bersama

d. Menentukan parameter sekolah

e. Identifikasi terhadap kebutuhan manajemen sekolah

f. Memberi dukungan terhadap layanan dan leadership

g. Menetapkan kebutuhan peserta didik.

Sedangkan untuk peran kepala sekolah sebagai seorang pemimpin dapat diterangkan sebagai berikut:

a. Dengan meningkatkan efektivitas organisasi sekolah dan membangun konteks organisasi yang akan memudahkan kesuksesan manajemen sekolah agar mudah untuk memenuhi kebutuhan leadership dan manajemen sekolah.

b. Memberikan hasil untuk memahami faktor yang mempengaruhi fungsi dan kesuksesan manajemen sekolah yang nantinya dapat membantu dinas pendidikan dan komite sekolah/madrasah dalam setting sekolah tertentu.

Penjelasan tersebut dapat dirupakan penilaian konteks perubahan, kebutuhan dan manajemen sekolah, serta budaya organisasi sekolah. Ketiga hal ini saling berhubungan dan kewenangannya terjalin antara dinas pendidikan, pemimpin lembaga pendidikan dan komite sekolah/madrasah.

Berdasarkan hal tersebut, komite sekolah/madrasah dengan komitmen dan semangatnya yang tingi juga harus menganalisis setiap perubahan yang ada dalam 4 bidang peningkatan. Mulai peningkatan proses pembelajaran, pendidik dan kesejahteraannya, sarana prasarana yang lebih baik, dan perbaikan lingkungan fisik sekolah. Sehingga dengan begini, komite sekolah/madrasah benarbenar menjadi wadah bagi aspirasi dan prakarsa masyarakat terhadap dunia pendidikan untuk menghasilkan sumber daya manusia yang berkualitas.

\section{PERAN KOMITE SEKOLAH/MADRASAH}

Maju dan mundurnya pendidikan merupakan tanggung jawab bersama baik antara orang tua, masyarakat dan pemerintah. Namun pernyataan tersebut sampai saat ini hanya masih bersifat slogan dan masih jauh dari harapan yang sebenarnya, meskipun ada beberapa lembaga pendidikan yang semua komponennya ikut aktif dengan baik. Dapat dikatakan bahwa tanggung jawab dari masing-masing komponen tersebut masih belum optimal dan maksimal, terutama peran serta masyarakat yang sampai saat ini masih belum banyak dirasakan dan diberdayakan secara merata.

Seperti yang dijelaskan dalam Undang-Undang No 20 Tahun 2003 tentang sistem pendidikan nasional, pada pasal 54 mengemukakan bahwa:

a. Dalam pendidikan, peran serta masyarakat meliputi peran serta perseorangan, kelompok, keluarga, organisasi profesi, pengusaha dan organisasi kemasyarakatan dalam penyelenggaraan dan pengendalian mutu pelayanan pendidikan,

b. Masyarakat dapat berperan serta sebagai sumber, pelaksana dan pengguna hasil pendidikan.(Mas, 2011, p. 189) 
Lebih khususnya pada pasal 56 Undang-Undang system pendidikan Nasional disebutkan bahwa di dalam Masyarakat ada Dewan Pendidikan dan Komite Madrasah yang berperan:

a. Masyarakat berperan dalam peningkatan mutu pelayanan pendidikan yang meliputi perencanaan, pengawasan, dan evaluasi program pendidikan melalui dewan pendidikan dan komite madrasah;

b. Dewan Pendidikan sebagai lembaga mandiri dibentuk dan berperan dalam peningkatan mutu pelayanan pendidikan dengan memberikan pertimbangan, arahan dan dukungan tenaga, sarana dan prasarana serta pengawasan pendidikan ditingkat nasional, provinsi, dan kabupaten/kota yang tidak mempunyai hubungan yang hierarkis;

c. Komite Madrasah sebagai lembaga mandiri dibentuk dan berperan dalam peningkatan mutu pendidikan dan memberikan pertimbangan, arahan, dan dukungan tenaga, sarana dan prasarana serta pengawasan pendidikan pada tingkat satuan pendidikan.

Kemudian ditegaskan lagi oleh Pemerintah melalui Keputusan Menteri Pendidikan Nasional Nomer 044/U/2002 yang menjelaskan Dewan Pendidikan dan komite sekolah/madrasah diharuskan untuk membentuk komite sekolah/madrasah. Dan diharapkan dapat meningkatkan pengawasan terhadap kinerja satuan pendidikan dalam menjalankan setiap kebijakan pendidikannya.(Lathifah, 2017, p. 355)

Sebagai sebuah organisasi yang mewadahi aspirasi masyarakat, komite sekolah/madrasah juga memiliki peran yang penting. Peran komite sekolah/madrasah tidak dapat berdiri sendiri, namun saling terkait antara peran satu dengan peran lainnya. Dapat dijelaskan sebagai berikut:

a. Advisory agency (pemberi pertimbangan). Komite sekolah/madrasah berperan sebagai pemberi pertimbangan kepada kepala sekolah atau lembaga pendidikan. Yang idealnya harus meminta pertimbangan yang berkaitan dengan merumuskan kebijakan, program, dan kegiatan. Termasuk juga dalam merumuskan visi misi beserta tujuan sekolah/madrasah. Meskipun tidak secara keseluruhan ada beberapa visi misi dan tujuan serta program unggulan apa yang harus dirumuskan bersama dengan komite sekolah/madrasah.(Anwar, 2015, p. 167)

b. Supporting agency (pendukung). Badan yang memberikan dukungan baik yang berwujud biaya operasional, pikiran, dan tenaga. Jika dulu peran komite sekolah/madrasah lebih sebagai pendukung pembiayaan, padahal penekanannya bukan pada aspek biaya saja melainkan pada banyak aspek lainnya, terutama berupa gagasan dalam rangka penyelenggaraan dan peningkatan mutu pendidikan.(Sagala, 2008, p. 57)

c. Controlling agency (pengawas) dalam upaya transparansi dan akuntabilitas penyelenggaraan pendidikan. Komite sekolah/madrasah berperan sebagai pengawas yang melaksanakan pengawasan social kepada satuan pendidikan. Pelaksanaannya tidak sama seperti pengawasan oleh badan pemerintah, namun hanya bersifat preventif saja.(Hanafi \& Ma'sum, 2015, p. 63)

d. Executive. Peran komite sekolah/madrasah sebagai mediator antara orang tua dan masyarakat, serta dengan pemerintah (eksekutif) dan dewan perwakilan rakyat daerah (legislatif) di satuan pendidikan.(Megiati, 2016, p. 128)

Apabila komite sekolah/madrasah dapat berperan dengan baik, tentu pihak komite dapat memberikan dampak positif pada sistem kinerja yang ada. Suatu hal yang penting untuk selalu diingat adalah memberdayakan dan meningkatkan peran masyarakat khususnya Komite sekolah/madrasah sebagai mitra dan pendamping hubungan dan kerjasama yang baik antara pihak sekolah/madrasah dengan orang tua dan masyarakatnya. sehingga tercipta suasana menyenangkan dan kondusif bagi peserta didik dan seluruh warga sekolah. 


\section{FUNGSI KOMITE SEKOLAH/MADRASAH}

Karena masyarakat harus ikut andil dan berpartisipasi dalam pengembangan pendidikan, salah satunya dengan melalui lembaga atau organisasi komite sekolah/madrasah yang dalam pelaksanaan perannya, komite sekolah/madrasah juga mampu berfungsi sebagai berikut:

a. Meningkatkan kepedulian dan komitmen orang tua dan masyarakat agar terlaksananya pemerataan pendidikan.(Anwar, 2015, p. 170)

b. Mengupayakan agar ada kerjasama antara lembaga pendidikan dengan seluruh komponen masyarakat maupun pemerintah, berkaitan penyelenggaraan pendidikan.(Hakim, 2019, pp. 126-127)

c. Menampung dan menganalisis segala bentuk aspirasi yang dibutuhkan lembaga pendidikan dan yang diajukan masyarakat.(Hikmah, 2016, p. 2039)

d. Memberi saran, pertimbangan, dan rekomendasi kepada lembaga pendidikan terkait:(Misbah, 2009, p. 13)

a) Kebijakan dan program pendidikan

b) Rencana Anggaran Pendidikan dan Belanja Sekolah (RAPBS)

c) Kriteria kinerja lembaga pendidikan

d) Kriteria tenaga lembaga pendidikan

e) Kriteria fasilitas lembaga pendidikan

f) Dan segala hal yang berhubungan dengan lembaga pendidikan.

e. Menggalang dana dari seluruh komponen masyarakat dalam rangka pembiayaan operasional lembaga pendidikan(Misbah, 2009, p. 5)

f. Melaksanakan evaluasi dan kontrol secara berkala terkait kebijakan, program, pelaksanaan pendidikan, dan out put di lembaga pendidikan.(Mulyono, 2014, p. 394)

Komite sekolah/madrasah dalam melaksanakan peran dan fungsinya memiliki tanggungjawab, diantaranya:

a. Menyampaikan hasil kajian dan evaluasi yang dilakukan komite dalam pelaksanaan program sekolah kepada stakeholder secara berkala dalam pencapaian tujuan program sekolah.

b. Membuat dan menyampaikan laporan pertanggungjawaban kepada masyarakat dan pemerintah yang berkaitan dengan bantuan baik berupa materi maupun non materi.(Mursidi, 2013, p. 26)

Dengan dibentuknya komite sekolah/madrasah ini dimaksudkan agar masyarakat memiliki wadah yang mempunyai komitmen dan peduli terhadap peningkatan kualitas pendidikan. Komite sekolah/madrasah yang dibentuk antara warga masyarakat dan sekolah bisa berciri khas dan berakar dari budaya masyarakat setempat. Hal ini mengingat komite sekolah/madrasah mengembangkan organisasi pengguna, berbagi kewenangan dan partnership yang difokuskan pada peningkatan mutu pelayanan pendidikan.

\section{PEMBENTUKAN KOMITE SEKOLAH/MADRASAH}

Pembentukan komite sekolah/madarsah akan menumbuhkan rasa peduli dan partisipasi masyarakat terhadap pendidikan. Di samping itu, pihak lembaga pendidikan dapat memaksimalkan proses pembelajarannya yang selama ini pemerintah banyak melakukan intervensi. Karena jika terus bergantung pada pemerintah tentu menjadikan peserta didik kurang dalam perkembangannya secara mandiri dalam menyelesaikan persoalan dirinya.(Hakim \& Rahayu, 2019, p. 24) Dan proses pembentukan ini sangat menentukan keberhasilan sebuah lembaga pendidikan dalam pelaksanaan peran dan fungsi komite sekolah/madrasah.

Ketika lembaga pendidikan membentuk komite sekolah/madrasah, maka perlu menganut pada tiga prinsip manajemen modern. Diantara tiga prinsip tersebut yaitu transparansi, akuntabel, dan demokratis.(Anwar, 2015, p. 170) Prinsip transparansi ini mendorong agar dalam proses 
pembentukan terdapat keterbukaan dan diketahui oleh masyarakat secara luas. Baik mulai pembentukan panitia, proses sisialisasi, kriteria calon anggota, proses seleksi, pengumuman hasil seleksi, proses dan penyampaian hasil pemilihan. Sedangkan dilaksanakan sesuai prinsip akuntabel adalah upaya pertanggung jawaban oleh pihak panitia terkait kinerja maupun penggunaan dana kepada masyarakat. Dan dilakukan dengan demokratis agar proses pemilihan pengurus dan anggota komite lebih berkualitas dan hasil yang didapat tentu dapat diterima semua pihak karena berasal dari hasil musyawarah mufakat.

Dan jika selama proses pembentukan komite sekolah/madrasah tidak sesuai dengan ketiga prinsip di atas, tentunya komite tersebut hanya akan menjadi komite yang asal dibentuk dan peran serta fungsinya tidak akan pernah optimal.

Apabila ingin membentuk komite sekolah/madrasah, langkah awal yang perlu dilakukan adalah dengan membentuk panitia persiapan.(Marsofiyati \& Febriantina, 2016, p. 207) Tugas operasional panitia persiapan ini adalah menyusun rencana pembentukan komite sekolah/madrasah melalui langkah-langkah berikut ini:

1) Mensosialisasikan pembentukan komite. Sosialisasi ini menjadi penting karena dapat memberikan pemahaman kepada semua lapisan masyarakat terkait komite sekolah/madrasah. Untuk proses sosialisasi yang dapat di dengar dan direspon oleh masyarakat, bisa dengan cara rapat diskusi, atau bahkan dalam konteks yang lebih luas, misalnya dengan menyebar brosur, pamflet, surat kabar, bulletin, pengumuman di radio, atau bahkan televisi.

2) Membuat kriteria calon anggota komite yang harus disepakati bersama. Dan dari kriteria yang dibuat tersebut, identifikasikan kepada nama-nama calon yang paling banyak memenuhi syarat.

3) Panitia melakukan seleksi calon anggota dengan berpatokan usulan dari masyarakat, yang disesuaikan dengan kriteria yang sudah ditentukan.

4) Setelah proses seleksi terlaksana, maka tugas panitia mengumumkan nama-nama calon yang lolos kepada masyarakat.

5) Pihak lembaga pendidikan kemudian memberi fasilitasi agar pemilihan pengurus dapat terlaksana dengan baik. Dan proses penyusunan pengurus dan anggota perlu berjalan secara demokratis dan transparan, dan pihak birokrasi pun tidak boleh melakukan hal-hal yang bersifat intervensi.

6) Langkah akhir setelah menyusun pengurus dan anggota komite sekolah/madrasah, maka panitia perlu menyerahkan nama-nama tersebut untuk diterbitkan dalam Surat Keputusan oleh Kepala Madrasah.(Marsofiyati \& Febriantina, 2016, pp. 207-208)

Kredibilitas sebuah komite sebagai organisasi, ditentukan oleh bagaimana mereka dibentuk dan hal ini juga menentukan tingkat kepercayaan civitas akademika terhadap meraka. Dan apabila struktur sebuah organisasi sudah terbentuk, maka hal yang paling urgen adalah cara untuk memaksimalkan kekuatan dan meminimalkan kelemahannya agar dalam proses menjalankan semua programnya dapat lebih memudahkan.

Sedangkan tugas pertama yang harus dilakukan pihak komite adalah menjelaskan beberapa elemen berikut ini. Elemen-elemen ini harus dijelaskan karena bertujuan memahamkan mereka atas peran dan fungsi mereka sendiri yang nantinya dapat berjalan dengan baik sebagaimana mestinya. Diantara elemen-elemen tersebut adalah:

a) Konsep dasar dibentuknya komite sekolah/madrasah, yang lingkupnya terkait definisi tujuan, wewenang dalam membuat keputusan, dan upaya pelaksanaan manajemen berbasis sekolah.

b) Kriteria efektifitas lembaga pendidikan yang dinilai oleh Dinas Pendidikan

c) Harapan Dinas Pendidikan terhadap manajemen berbasis sekolah

d) Aspek-aspek keputusan khusus yang diberi oleh Dinas Pendidikan kepada komite sekolah/madrasah

e) Daftar program lanjutan tingkat daerah di sekolah/madrasah 
f) Pemahaman terhadap tanggung jawab decision-maker bagi dewan penasehat dan kelompok pembuat keputusan lainnya.(Raynolds, 2005, p. 125)

Tugas kedua pihak komite adalah memberi penjelasan dan pemahaman mengenai apa saja faktor-faktor yang dapat membantu komite sekolah/madrasah dalam pengembangan pendidikan kepada seluruh struktur dan anggota komite sekolah/madrasah yang terbentuk.(Misbah, 2009, pp. 6-7) Disamping hal itu, setting oleh pihak lembaga pendidikan akan menentukan banyak tidaknya kriteria yang diajukan kepada komite. Seperti halnya sejarah lembaga, masalah dan persoalannya, keterlibatan komite dalam kelompok penasehat dan pembuat keputusan dimasa sebelumnya, serta kekuatan dan kelebihan anggota komite termasuk beberapa pertimbangan yang penting.

Namun selain kriteria yang telah disebutkan di atas, efektifitas keberhasilan program pembelajaran yang dilaksanakan pihak sekolah/madrasah tergantung pada kemampuan peserta didik dalam memaksimalkan potensi yang mereka miliki. Dan pihak komite sekolah/madrasah sangat diharapkan menjadi pusat peserta didik dalam segala kebutuhan. Bukan hanya menjadi pusat kaum dewasa dan menekankan sebuah pandangan bahwa "swasta sebagai konsumen".(Raynolds, 2005, pp. 126-127)

Oleh karena itu decicion-maker menentukan ukuran besarnya pengaruh langsung kemampuan komite dalam mengoptimalkan kekuatan yang dimiliki serta menyederhanakan kelemahan anggotanya.(Dacholfany, 2016, p. 20) Karena rasa peduli dam partisipasi merupakan tujuan utama, dan hal ini sering kali pihak lembaga mencoba memasukkan wakil-wakilnya dari setiap stakeholder dalam lembaga negeri. Dan diantara mereka ada yang beranggapan bahwa membawa satu wakil merupakan hal baik dan memang perlu diikut sertakan.

Sedangkan alasan yang mendasari dalam upaya menghindari ukuran kelompok yang dirasa sesuai untuk membantu tujuan manajemen berbasis sekolah adalah karena tugas-tugas pihak sekolah terpusat pada penyelesaian pada perencanaan strategis, menciptakan dan mewujudkan visi bersama, dan sebagian percaya bahwa kelompok kecil jauh lebih baik dalam penanganannya. Kelompok kecil yang dimaksud di sini berkisar antara 8-10 orang, dan tentunya dengan mengikut sertakan kepala sekolah/madrasah, semua pendidik, dan orang tua. Sehingga tentu mudah untuk mendapatkan anggota tersebut. Dan alasan kedua, jumlah panitia yang sedikit dikarenakan pendidik biasanya sibuk dengan urusan dan tugas masing-masing dan tentu menyita waktu. Dan untuk alasan terakhir, karena dengan kelompok kecil tentu dalam memulai sesuatu dapat dilakukan dengan perlahan dan lebih mudah mengatur jadwal pertemuan maupun membangun kerjasama yang positif. Serta pihak komite sekolah/madrasah harus fokus pada langkah awal perkembangan kelompoknya.(Raynolds, 2005, p. 128)

Kelompok decision maker memiliki kekuatan yang potensial dalam hal pandangan, wawasan pengetahuan, dan ketrampilan anggota yang dihasilkan.(Suhayati, 2013, p. 91) Karena pihak komite harus bisa merefleksikan keberagaman komunitas yang dimiliki seperti peserta didik, orang tua, tenaga pendidik dan kependidikan, maka komite bertanggung jawab terhadap perencanaan strategis, visi bersama, maupun efektivifitas program dan layanan pendidikan. Kredibilitas dan legitimasi manajemen berbasis sekolah bergantung pada hal ini.

Dan yang menentukan produktifitas maupun kepuasan setiap anggota komite adalah status formal yang dimiliki oleh setiap anggota. Oleh karenanya tidak heran jika komite menggunakan hierarki peran formal tradisional dalam kelompoknya, yang mana mereka menekankan pada polapola lama dan tentu dikuasai oleh orang yang berstatus tinggi.(Fauziyah, 2017, p. 1349) Hal tersebut tentu sangat mempengaruhi kemampuan manajemen berbasis sekolah untuk menjadi agen perubahan yang signifikan dalam membuat keputusan bersama maupun proses pendidikannya.

Jika diidentifikasi lebih lanjut, hal pertama terjadi bila posisi formal kepala sekolah lebih tinggi dari para peserta didik dan keinginan kepala sekolah untuk melanjutkan control dan pemenuhan kebutuhan yang mengakibatkan usaha untuk menguasai kelompok. Kedua, beberapa lembaga pendidikan percaya pada manajemen berbasis sekolah namun tidak ada antusias yang diberikan oleh pihak orang tua dan masyarakat dalam keanggotaan komite sekolah/madrasahnya. 
Ketiga, para peserta didik memiliki pengaruh yang sangat kecil ketika membahas prioritas dalam peningkatan lembaga pendidikannya. Disaat yang sama pendidik lebih peduli pada peserta didik yang ingin akan tanggung jawab yang lebih dari seharusnya. Dan keempat, di sebagian daerah anggota komite juga merangkap menjadi anggota tim di lembaga pendidikan. Dan keanggotaan ganda ini perlu untuk dihindari dalam hal decision maker, karena anggota di lembaga pendidikan mempunyai tugas dan fungsi yang berbeda dalam lingkup lingkungan daerah.(Raynolds, 2005, pp. 129-130)

Harapannya terhadap semua aturan yang diperuntukkan untuk komite sekolah/ madrasah agar nantinya dapat mengenali potensi dalam memberikan kontribusi oleh setiap individu ataupun kelompok yang diwakili. Akan tetapi, pada umumnya aturan dalam kelompok seharusnya berbentuk pertanyaan awal tentang kelompok seperti apa yang diharapkan untuk bekerjasama. Dan ketika tim sudah terbentuk, hal ini perlu diperbaiki, karena secara hakiki aturan setiap individu di dalam komite harus disesuaikan dengan perilaku kepala sekolah yang sangat penting dalam membangun sebuah kepercayaan.

\section{PROGRAM KERJA KOMITE SEKOLAH/MADRASAH}

Dalam menggerakkan sebuah organisasi, sedah seharusnya untuk menyusun program kerjanya secara rapih, baik program kerja dalam jangka pendek, jangka menengah, maupun jangka panjang.(Mursidi, 2013, p. 21) Semua hal ini sangat penting untuk segera disusun setelah komite terbentuk, dan sudah memiliki anggaran dasar dan anggaran rumah tangga (AD/ART).(Misbah, 2009, p. 7)

Untuk menyusun program kerja komite sekolah/madrasah, perlu diperhatikan hal-hal sebagai berikut:

a. Program kerja komite dari uraian peran dan fungsi.(Mursidi, 2013, p. 24) Program komite dianjurkan masih dalam koridor atau abstraksi yang berasal dari peran dan fungsi komite sekolah/madrasah.

b. Didasarkan pada data/ informasi yang sesuai dengan situasi maupun kondisi permasalahan lembaga pendidikan.(Sholihat, 2017, p. 9) Oleh karenanya dalam penyusunan program kerja komite dianjurkan bekerja sama dengan pihak lembaga pendidikan.

c. Penyusunan program kerja komite menganut kaidah SMART (Specific, Measurable, Achievable, And Time Frame).(Rohayati et al., 2014) SMART yang dimaksud dalam hal ini yakni menjadikan program kerja komite yang spesifik dan terukur keberhasilan dan pencapaiannya. Dan kemungkinan dapat dicapai dan diperoleh serta tidak mempersulit ketika fokus pada hasil maupun proses yang terjadwal dengan jelas.

d. Dapat dipertanggung jawabkan pelaksanaannya.(Mursidi, 2013, p. 26) Yang dimaksud dalam hal ini adalah akuntabilitas, yang mana semua pelaksanaan program kerja komite harus dipertanggung jawabkan bukan hanya kepada orang tua saja namun kepada masyarakat juga.(Hakim, 2016, p. 108) Sekolah dan komite harus membuat laporan pertanggungjawaban secara periodik atau setiap akhir tahun pelajaran kepada orang tua siswa dan masyarakat. Hal ini sama dengan apa yang dilakukan oleh institusi pemerintah yang memiliki kewajiban untuk membuat Laporan Akuntabilitas Kinerja Instansi Pemerintah (LAKIP) pada setiap akhir tahun kegiatan.

\section{ANGGARAN DAN FASILITAS KOMITE SEKOLAH/MADRASAH}

Setiap organisasi membutuhkan dana untuk pembiayaan dan fasilitas, sama halnya dengan komite. Ada tiga sumber anggaran yang dapat diperoleh oleh komite sekolah/madrasah. Yang dimaksud dalam hal ini belum adanya aturan pasti untuk menganggarkan dana maupun pengadaan fasilitas dalam ketentuan undang-undang. Diantara ketiga sumber tersebut yaitu: 
a. Dana Komite Madrasah berasal dari subsidi stimulan dari pemerintah pusat (Depdiknas). Sebagai subsidi stimulan dari pemerintah pusat (Departemen Pendidikan Nasional) dan pemerintah daerah, maka dana ini mungkin tidak terlalu besar mendorong komite sekolah/madrasah untuk dapat menjalankan roda organisasinya. Dengan dana yang sedikit ini, diharapkan agar komite sekolah/madrasah dapat menjalankan program dan kegiatan operasionalnya. Dan tentu saja, dana stimulan ini tidak akan diterima seterusnya. Suatu saat apabila organisasi ini sudah dapat membiayai dirinya sendiri maka dana ini dapat saja diberhentikan.

b. Dana Komite Madrasah berasal dari APBD, yang diharapkan akan menjadi dana pendukung untuk meningkatkan kinerja Komite Madrasah.

c. Dana Komite Madrasah berasal dari orang tua, masyarakat termasuk dari dunia usaha dan dunia industri (DU-DI). Untuk menggalang dana dari masyarakat dunia usaha dan dunia industri (DU-DI) komite sekolah/madrasah dipastikan harus dapat menyusun proposal. berikut:

Berkaitan dengan persoalan tersebut, pihak komite perlu berpedoman pada prinsip-prinsip

a. Transparansi dan akuntabilitas

Semua hal yang berkaitan dengan pembiayaan sepenuhnya ditemukan dalam AD dan ART maupun hasil rapat pengurus. Sehingga pengurus komite perlu menyusun laporan periodik yang dilakukan setiap akhir tahun.(Lathifah, 2017, p. 361)

b. Insentif pengurus

c. Sebagian besar anggota komite merupakan tenaga yang bekerja secara sukarela dan tidak menjadikannya sumber penghasilan. Akan tetapi pihak komite dapat memperoleh dana agar pelaksanaan program, kegiatan, maupun hal lain dapat terlaksana dengan baik jika hal tersebut telah diatur dalam AD dan ART.

d. Kantor dan fasilitasnya

Kantor dan fasilitas kantor memang sangat diperlukan oleh komite untuk hal administrasi dan lainnya.(Pantjastuti et al., 2008, pp. 103-104) Semisal data dan informasi perlu tempat menyimpan karena diperlukan untuk merumuskan kebijakan dan rencana kerja mereka. Untuk itu, pihak sekolah/madrasah perlu untuk menyediakan ruang khusus bagi komite sekolah/madrasah.

\section{ORGANISASI KOMITE SEKOLAH/MADRASAH}

1. Keanggotaan Komite Sekolah/Madrasah

Di zaman manajemen berbasis sekolah yang menuntut pembenahan dalam pengelolaan pendidikan sejalur dengan perubahan yang berlandaskan kesepakatan, komitmen, dan profesionalisme untuk mewujudkan masyarakat yang loyal dalam peningkatan mutu sekolah/madrasah.(Hakim, 2018, p. 78) Oleh sebab itu anggota komite dapat melibatkan dewan pendidik dalam mengawal pendidikan peserta didik, lembaga pendidikan untuk terus mengembangkan dan meningkatkan program pendidikannya, serta badan permusyawaratan desa agar lebih giat mengarahkan stakeholder pendidikan untuk peduli dan berkontribusi kepada dunia pendidikan.

Anggota komite dari unsur masyarakat berasal dari beberapa komponen, diantaranya yang pertama dari perwakilan orang tua atau wali peserta didik, yang dipilih secara demokratis. Kedua, dari pejabat pemerintah setempat maupun tokoh masyarakat yang memiliki pengaruh atau menjadi public figure serta memiliki perhatian untuk peningkatan mutu pendidikan. Ketiga, berasal dari du-di (pengusaha industri barang dan jasa, asosiasi, dll). Keempat, para ahli dalam pendidikan yang bias berasal dari organisasi profesi tenaga pendidikan. Kelima, beberapa wakil dari alumni yang dirasa telah mumpuni dan mandiri sehingga dapat berkontribusi dalam meningkatkan kualitas pendidikan.(Misbah, 2009, p. 6) 
Untuk anggota komite yang berasal dari lembaga pendidikan yang bersangkutan dapat berasal dari dewan pendidik. Jika diperinci, keseluruhan anggota komite sekurangkurangnya berjumlah sembilan orang. Dan untuk semua ketentuan seperti syarat, hak, kewajiban, dan keanggotaan komite ditetapkan dalam AD dan ART.

2. Kepengurusan Komite Sekolah/Madrasah

Penetapan pengurus komite sekolah/madrasah yang didasarkan AD dan ART minimal terdiri atas ketua, sekretaris, bendahara, dan beberapa bidang tertentu untuk menyesuaikan terhadap kebutuhan komite. Dalam pemilihan pengurus komite sekolah/madrasah dipilih secara demokratis. Dan khusus untuk jabatan bagi ketua komite tidak boleh dari kepala satuan pendidikan.(Marsofiyati \& Febriantina, 2016, p. 206) Sebab ketua komite tidak harus dari kepala satuan pendidikan, dan bila terjadi hal yang seperti itu tentu akan mengganggu jalannya kinerja dari komite sekolah/madrasah terhadap upaya peningkatan kualitas sekolahnya.

Komite sekolah/madrasah dalam menangani urusan-urusan administrasinya diperbolehkan mengangkat staf khusus yang memiliki keahlian dibidangnya, yang mana staf ini juga tidak diperbolehkan berasal dari staf/pegawai satuan pendidikan. Dan untuk mengangkat staf khusus ini pun harus berdasarkan kesepakatan rapat komite sekolah/madrasah.(Megiati, 2016, p. 130)

Jika diidentifikasi untuk mekanisme kerja dari pengurus komite sekolah/madrasah maka dapat dijelaskan bahwa para pengurus komite yang terpilih bertanggung jawab atas musyawarah anggota sebagai forum tertinggi sesuai dengan apa yang tertera dalam AD dan ART. Kemudian komite baru menyusun program yang telah disetujui pada saat musyawarah seluruh anggota komite yang didasarkan peningkatan kualitas pendidikan.

Selanjutnya, pengurus komite yang terpilih dan dinilai tidak atau kurang produktif dalam masa jabatannya, akan dimusyawarahkan oleh anggota agar dapat diberhentikan dan mengganti dengan pengurus baru. Dan yang terakhir untuk pembiayaan bagi pengurus komite dapat diambil dari anggaran yang telah ditetapkan melalui musyawarah oleh seluruh anggota sebelumnya.(Misbah, 2009, p. 7)

Sehingga diharapkan komite sekolah/madrasah dapat menyusun dan mewujudkan program kerja yang sinergi dengan pihak lembaga pendidikan dalam meningkatkan kualitas pendidikan, yang fokus kepada peserta didik, pendidik maupun tenaga kependidikan.

3. AD dan ART Komite Sekolah/Madrasah

Sebagai sebuah organisasi, komite sekolah/madrasah wajib memiliki Anggaran Dasar dan Anggaran Rumah Tangga, karena masa jabatan dari para pengurus komite sekolah/madrasah diatur di dalamnya seperti halnya yang tertuang dalam PP nomor 17 tahun 2010 pasal 197 yang menegaskan bahwasanya keanggotaan sebuah komite sekolah/madrasah adalah 3 tahun dan setelah itu dapat dipilih kembali untuk masa jabatan berikutnya.(Anwar, 2015, p. 169)

Hal tersebut dimaksudkan agar ada pedoman bersama yang disepakati dan ditetapkan oleh seluruh anggota dan pengurus, sehingga memudahkan mereka dalam menjalankan program-program yang mereka rencanakan untuk meningkatkan mutu sekolah.

Selanjutnya, anggaran dasar komite sekurang-kurangnya berisi tentang: a) nama dan kedudukan; b) dasar, tujuan, dan kegiatan komite sekolah/madrasah; c) keanggotaan dan kepengurusan; d) hak dan kewajiban semua anggota dan pengurus komite sekolah/madrasah; e) keuangan; f) mekanisme kerja komite dan rapat-rapat yang perlu diagendakan; dan g) perubahan AD dan ART, serta pembubaran organisasi komite.(Marsofiyati \& Febriantina, 2016, p. 207)

Sedangkan untuk anggaran rumah tangga sekurang-kurangnya berisi tentang halhal seperti: a) mekanisme pemilihan dan penetapan anggota serta pengurus komite; b) 
rincian tugas komite; c) mekanisme rapat komite; d) kerja sama antara komite dengan pihak lain; e) ketentuan dan penutup.(Misbah, 2009, p. 7)

Dengan demikian komite sebagai partner dapat lebih konsisten dalam mengembangkan dan meningkatkan mutu sekolah/madrasah dengan adanya AD dan ART yang telah mereka tetapkan sebagai pedoman untuk menjalankan tugas dan perannya bagi sekolah/madrasah

\section{KESIMPULAN}

Komite sekolah/madrasah adalah lembaga independen dari unsur masyarakat, sekolah, dunia usaha dan dunia industri (du-di), perwakilan orang tua / wali peserta didik yang menjadi wadah aspirasi dalam rangka meningkatkan mutu pendidikan dalam segala tingkatan dan jalur pendidikan.

Selama proses pembentukan komite, proses awal merupakan proses yang paling menentukan dalam pelaksanaan peran dan fungsinya nanti. Dan dalam pembentukan komite ini perlu untuk menganut tiga prinsip yaitu transparansi, akuntabilitas dan demokratis. Sehingga dengan adanya komite, pihak lembaga pendidikan lebih mudah dalam penyelenggaraan pendidikan bukannya terbebani olehnya Adanya komite sekolah/madrasah dimaksudkan agar masyarakat yang mempunyai komitmen dan loyalitas serta peduli terhadap peningkatan kualitas pendidikan memiliki wadah untuk berkontribusi.

Komite sekolah/madrasah yang dibentuk antara warga masyarakat dan lembaga pendidikan bisa berciri khas dan berakar dari budaya masyarakat setempat. Hal ini mengingat komite sekolah/madrasah mengembangkan organisasi pengguna, berbagi kewenanagan dan partnership yang fokus utama mereka pada peningkatan kualitas dan pengembangan pelayanan pendidikan.

\section{REFERENSI}

Anwar, I. (2015). Kinerja Komite Sekolah Dalam Meningkatkan Kualitas Pendidikan Di SMP AL Khairat Kalumpang Kota Ternate. EDUKASI - Jurnal Pendidikan, 13(1), 165-177.

Dacholfany, M. I. (2016). Peranan pengambilan keputusan dalam rangka menciptakan inovasi di bidang pendidikan. Dewantara, 1(1), 16-28.

Desi Nurhikmahyanti, S. M. (2014). Prasarana Di Sd Negeri Pucang Iv Sidoarjo. Jurnal Inspirasi Manajemen Pendidikan, 4(4), 163-176.

Faqih, M., \& Mulianti, E. (2016). Peran Komite Sekolah dengan Mutu Pendidikan. Jurnal Visionary, 2(2), 108-113.

Fauziyah, H. (2017). Pengaruh Kohesifitas Kelompok Dan Kepuasan Kerja Terhadap Produktivitas Guru Raudhatul Athfal (Ra) Di Kabupaten Bekasi. Jurnal Manajemen Pendidikan, 7(2), 1346. https://doi.org/10.21009/jmp.07206

Fauziyati, W. R. (2018). Strategi Kepala Sekolah untuk Meningkatkan Partisipasi Masyarakat dalam Pendidikan menuju Generasi Maju Indonesia. Qalamuna, 10(1), 157-177.

Hakim, M. N. (2016). Implementasi Manajemen Berbasis Sekolah Dalam Mewujudkan Sekolah Islam Unggulan. Nidhomul Haq: Jurnal Manajemen Pendidikan Islam, 1(2), 104-114. https://doi.org/10.31538/NDH.V1I2.7

Hakim, M. N. (2018). Upaya Kepala Madrasah Dalam Membina Budaya Religius. IMProvement, 5(1), 74-88. https://doi.org/10.21009/Improvement.051.07

Hakim, M. N. (2019). Manajemen Hubungan Masyarakat Dalam Mengembangkan Lembaga Pendidikan (Studi Kasus di SMK Negeri 1 Dlanggu Mojokerto). Nidhomul Haq: Jurnal Manajemen Pendidikan Islam, 4(1), 121-139. https://doi.org/10.31538/ndh.v4i1.245 
Hakim, M. N., \& Hasan, M. T. (2019). Inovasi Kurikulum Pendidikan SMA Darul Ulum 2 di Pondok Pesantren Darul Ulum Jombang. Jurnal Manajemen Pendidikan Islam Al-Idarah, 4(2), $1-13$.

Hakim, M. N., \& Rahayu, F. D. (2019). Pembelajaran Saintifik Berbasis Pengembangan Karakter. Naz̧runa: Jurnal Pendidikan Islam, 2(1), 1-27. https://doi.org/10.31538/nzh.v2i1.148

Hanafi, I., \& Ma'sum, M. (2015). Analisis Implementasi Kebijakan Pendidikan: Peran Komite Sekolah pada Sekolah Menengah Kejuruan. Cakrawala Pendidikan, 34(1), 58-66.

Hikmah, N. (2016). Peran Komite Sekolah dalam Meningkatkan Mutu Pendidikan di SD N 2 Gemeksekti Kebumen. Jurnal Pendidikan Guru Sekolah Dasar, 5(21), 2036-2041.

Kamil, M. (2007). Kompetensi Tenaga Pendidik Pendidikan Nonformal Dalam. Jurnal Ilmiah VISI PTK-PNF, 2(2), 11-20.

Krissandi, A. D. Sagita., \& Rusmawan. (2015). Kendala Guru Sekolah Dasar Dalam Implementasi Kurikulum 2013. Cakrawala Pendidikean, 34(3), 457-467.

Lathifah. (2017). Peran Komite Sekolah dalam Proses Manajemen Madrasah pada MTsN Karang Intan Kabupaten Banjar. Jurnal Ilmiah Ekonomi Bisnis, 3(3), 354-364.

Marsofiyati, \& Febriantina, S. (2016). Pemberdayaan Komite Sekolah Dalam Meningkatkan Efisiensi Pengelolaan Sekolah Di Kota Depok (Studi Kasus pada Komite SMAIT AlQudwah Kota Depok). Jurnal Ilmiah Econosains, 14(2), 201-224.

Mas, S. R. (2011). Partisipasi Masyarakat dan Orang Tua dalam Penyelengaraan Pendidikan. Jurnal El-Hikmah, VIII(2), 184-196.

Megiati, Y. E. (2016). Pemberdayaan Komite Sekolah: Kajian Konsep dan Implementasinya. Jurnal SAP, 1(2), 217-227.

Misbah, M. (2009). Peran Komite Sekolah dalam Meningkatkan Mutu Pendidikan. Insania, 14(1), $1-15$.

Mulyono, W. D. (2014). Peran Komite Sekolah Dalam Penyelenggaraan Pendidikan Smk Di Kabupaten Lamongan, Jawa Timur the Rolesof the School Committee in the Implementation of Vocational High School in Lamongan Regency, East Java. Jurnal Pendidikan Vokasi, 4(3), 391-404.

Mursidi, A. (2013). Pengelolaan Komite Sekolah Dalam Meningkatkan Mutu Pendidikan Di Sd Islam Al Azhar 29 Semarang. JMP, 2(1), 20-32.

Pantjastuti, S. R., Haryanto, A., Suparlan, \& Yudistira. (2008). Komite sekolab: Sejarah dan prospeknya di masa depan. Hikayat.

Raynolds, L. J. (2005). Kiat Sukses Manajemen Berbasis Sekolah, Pedoman Bagi Praktisi Pedidikan. Diva Pustaka.

Ridwan, M. (2018). Konsep Tarbiyah, Ta'lim Dan Ta'dib Dalam Al-Qur'an. Nað̧bruna: Jurnal Pendidikan Islam, 1(1), 35-57. https://doi.org/10.31538/nzh.v1i1.41

Rohayati, T., Sudjarwo, \& Rini, R. (2014). Pengaruh Kepemimpinan Kepala Sekolah dan Peran Komite Sekolah Terhadap Kinerja Guru SMPN di Kecamatan Tulang Bawang Tengah Kabupaten Tulang Bawang Barat. Jurnal Manajemen Mutu Pendidikan, 2(3).

Rusdiana, A. (2014). Konsep Inovasi Pendidikan (1st ed.). PUSTAKA SETIA.

Sagala, S. (2008). Dukungan Dan Partisipasi Masyarakat Dalam Penyelenggaraan Pendidikan Khususnya Di Sekolah. GENERASI KAMPUS, 1(2), 49-63.

Sa'ud, U. S., \& Makmun, A. S. (2009). Perencanaan Pendidikan (IV). PT Remaja Rosdakarya.

Sholihat, S. S. (2017). Pengelolaan Biaya Pendidikan, Partisipasi Masyarakat, dan Mutu Layanan Pembelajaran Madrasah Ibtidaiyah Swasta. Jurnal Administrasi Pendidikan, XXIV(1), 1-10.

Sudirman. (2013). Kontribusi Partisipasi Komite Terhadap Mutu Layanan Pendidikan Di Man SeKabupaten Tanah Datar. Al-Fikrah: Jurnal Manajemen Pendidikan, 1(2), 183-191. https://doi.org/10.31958/jaf.v1i2.363

Suhayati, I. Y. (2013). Supervisi kademik Kepala Sekolah, Budaya Sekolah dan Kinerja Mengajar Guru. Jurnal Administrasi Pendidikan, 17(1), 86-95. 
Abdul Mukti Bisri

64 Munaddhomah: Jurnal Manajemen Pendidikan Islam, Volume 1, Issue. 1, 2020, pp. 51-64 